\title{
ESOPHAGEAL MANOMETRY FINDINGS AND DEGREE OF ACID EXPOSURE IN SHORT AND LONG BARRETT'S ESOPHAGUS
}

\author{
Laura HELMAN ${ }^{1}$, Beatriz Nunes BICCAS ${ }^{2}$, Eponina M. O. LEMME ${ }^{3}$, Paula NOVAIS ${ }^{4}$ and \\ Viviane FITTIPALDI ${ }^{5}$
}

\begin{abstract}
Context - Barrett's esophagus (BE) is characterized by intestinal metaplasia in the distal esophagus and is classified as short-segment $(<3 \mathrm{~cm}-\mathrm{SSBE}$ ) or long-segment ( $>3 \mathrm{~cm}-$ LSSBE). It is suggested that LSSBE is associated with more severe esophageal motor abnormalities and increased acid exposure time than SSBE. Objective - To evaluate the prevalence of esophageal manometriy abnormalities and acid exposure times in patients with SSBE and LSSBE. Methods - Barrett's esophagus patients identified by upper endoscopy and confirmed by histopathology were, retrospectively, reviewed and divided into two groups: SSBE and LSBE. Demographic data, symptom duration, prevalence of hiatal hernia, lower esophagus sphincter basal pressure, prevalence of esophageal body abnormalities and acid exposure times were evaluated. Results - Forty-six patients with SSBE (24 males - 52.2\%, mean age of 55.2 years) and 28 patients with LSBE (18 males - 64.3\%, mean age of 50.5 years). Mean symptom duration was 9.9 years for SSBE and 12.9 years for LSSBE. Hiatal hernia was present in 84.2\% of SSBE, 96.3\% of LSBE; average lower esophagus sphincter pressure in SSBE $9.15 \mathrm{~mm} \mathrm{Hg}$, in LSBE $6.99 \mathrm{~mm} \mathrm{Hg}$; lower esophagus sphincter hypotension in SSBE was $65.9 \%$, in LSSBE 82.1\%; aperistalsis in SSBE 6.5\%, LSSBE 3.6\%; mild/moderate ineffective esophageal motility in SSBE 34.8\%, LSBE 46.4\%; severe moderate ineffective esophageal motility in SSBE 10.9\%, LSBE 7,1\%; nutcracker esophagus/segmental nutcracker esophagus in SSBE 8.6\%, LSBE 0\%; normal body in SSBE 39.1\%, in LSBE 42.9\%, no statistical difference for any of these values $(P<0.05)$. Average \% total time $\mathrm{pH}<4$ in SSBE 9.12, LSBE $17.27(P<0.000) ; \%$ time $\mathrm{pH}<4$ upright in SSBE 11.91; LSBE $24.29(P=0.003) ; \%$ time $\mathrm{pH}<4$ supine in SSBE 10.86, LSBE $33.26(P=0.000)$. Conclusion - There was no difference between the prevalence of motor disorders in patients with SSBE and LSSBE. Acid reflux in upright and supine positions was more intense in LSBE.
\end{abstract}

HEADINGS - Barrett esophagus. Gastroesophageal reflux. Manometry. Esophageal motility disorders.

\section{INTRODUCTION}

Gastro-esophageal reflux disease (GERD) can present in erosive and, nonerosive forms and as complications. Barrett's esophagus (BE) is a complication, which has attracted much attention because of its malignancy potencial. It is characterized by the presence of intestinal metaplasia in the distal esophagus ${ }^{(20)}$. This metaplasic segment is called short Barrett's esophagus (SSBE) when its length is less than $3 \mathrm{~cm}$ and long Barrett's esophagus (LSBE), when it is $3 \mathrm{~cm}$ long or longer ${ }^{(14)}$.

$\mathrm{BE}$ pathophysiology is multiple. The main factors are chronic and prolonged acid and/or bile reflux. When compared to controls, BE patients present more pronounced motor abnormalities such as severe LES hypotension and esophageal body hypomotility ${ }^{(10,11,12)}$.

The aim of this study was to compare SSBE and LSBE with regard to demographic and esophageal manometriy characteristics and esophageal $\mathrm{pH}$ monitoring.

\section{METHODS}

The charts of patients with $\mathrm{BE}$ who underwent esophageal manometry and $\mathrm{pH}$ monitoring from March 1992 to March 2010 were reviewed. All were diagnosed with $\mathrm{BE}$ on the basis of endoscopic and biopsy findings described below and were divided into SSBE and LSBE groups.

\section{Endoscopy}

The examinations were performed on a fasting patient, after topical anesthesia of the oropharynx with lidocaine and under sedation. A sliding hiatal hernia was defined when the esophagogastric junction was displaced more than $2 \mathrm{~cm}$ above the diaphragmatic impression. Suspected $\mathrm{BE}$ was diagnosed when a salmon-pink epithelium similar to the gastric mucosa (columnar epithelium) was found above the gastro-esophageal junction. The diagnosis was confirmed histopathology when goblet cells (intestinal metaplasia) were found in this mucosa. SSBE was diagnosed when the metaplasia was less than

Unidade de Esôfago, Serviço de Gastroenterologia, Hospital Universitário Clementino Fraga Filho, Universidade Federal do Rio de Janeiro, RJ, Brasil.

Correspondence: Dr. Laura Helman - Praia de Botafogo, 252 - ap. 602 bloco A - Botafogo - 22250-040 - Rio de Janeiro, RJ, Brasil. E-mail: helman@ufri.br 
$3 \mathrm{~cm}$ long; LSBE was diagnosed when the metaplastic area was equal or longer than $3 \mathrm{~cm}^{(14)}$.

\section{Esophageal manometry}

All patients underwent esophageal manometry using a water-perfused polyvinyl catheter with eight lumens and an external diameter of $4.5 \mathrm{~mm}$, with four distal ports arranged radially at the same level and the four other ports spaced $5 \mathrm{~cm}$ apart from each other (Medtronic, Synectics, Sweden or Alacer Corp, SP, Brazil). Each opening was connected to an external pressure transducer perfused with distilled water using a pneumo-hydraulic capillary infusion system. The intraluminal pressure was recorded on a polygraph, digitized and transferred to a computer.

After local anesthesia with $2 \%$ viscous lidocaine applied to the nasopharynx, the catheter was passed into the stomach per the nares and withdrawn through the lower esophageal sphincter (LES) using the station pull-through technique at $1 \mathrm{~cm}$ increments every 20 seconds. The lower esophageal sphincter pressure (LESP) was defined as the difference between the end-expiratory gastric baseline pressure and the highest end-expiratory pressure just distal to the respiratory inversion point. It was calculated by the averaging the reading from the four radial ports and the relaxation was assessed after six wet swallows. Esophageal body contractions were then evaluated by the four ports (spaced $5 \mathrm{~cm}$ apart) after the patient took 10 wet swallows at 20 -second intervals. Appropriate software was used for interpretation.

For diagnosis of primary motility disorders the International Classification of Abnormalities ${ }^{(18)}$ was used, when appropriate to adjust the normal values employed in the Esophagus Unit of Clementino Fraga Filho University Hospital, Federal University of Rio de Janeiro, RJ, Brazil, which derived from a study of healthy volunteers as described in the chart (Figure 1) ${ }^{(9)}$.

\begin{tabular}{|c|c|}
\hline MOTILITY ABNORMALITY & MANOMETRIC FINDINGS \\
\hline $\begin{array}{l}\text { IEM (ineffective esophageal } \\
\text { motility) }\end{array}$ & $\begin{array}{c}>20 \% \text { of low amplitude } \\
\text { contractions }(<30 \mathrm{~mm} \mathrm{Hg}) \text { or } \\
\text { non-transmitted contractions in } \\
\text { the distal esophagus during } 10 \text { wet } \\
\text { swallows }\end{array}$ \\
\hline DES (diffuse esophageal spasm) & $\begin{array}{l}\geq 20 \% \text { of simultaneous } \\
\text { contractions in the distal } \\
\text { esophagus during } 10 \text { wet swallows }\end{array}$ \\
\hline NE (nutcracker esophagus) & $\begin{array}{c}\text { Mean distal amplitude of } \\
\text { esophageal contractions } \\
>140 \mathrm{~mm} \mathrm{Hg} \\
\end{array}$ \\
\hline LES $†$ hypotension & LESP $\ddagger>10 \mathrm{~mm} \mathrm{Hg}$ \\
\hline LES $†$ hypertension & LESP $\ddagger>32 \mathrm{~mm} \mathrm{Hg}$ \\
\hline Non-specific motor disorders & $\begin{array}{l}\text { Increased-duration }(>6 \mathrm{sec}) / \\
\text { and/or triple-peak or retrograde } \\
\text { contractions in more than } 20 \% \text { of } \\
\text { esophageal body swallows }\end{array}$ \\
\hline
\end{tabular}

$\dagger=$ Lower esophageal sphincter;

$\doteqdot=$ Lower esophageal sphincter pressure

FIGURE 1. Esophageal motility abnormalities
The term segmental nutcracker esophagus (SegNE) was used when the mean amplitude of distal esophagus segments ( 3 or $8 \mathrm{~cm}$ above the LES) was $>165 \mathrm{~mm} \mathrm{Hg}^{(1)}$.

Ineffective esophageal motility (IEM) is defined in the distal esophagus when at least $30 \%$ of 10 wet swallows exhibit any combination of the following abnormalities: (1) distal esophageal peristaltic wave amplitude $<30$ $\mathrm{mm} \mathrm{Hg}$, (2) simultaneous contractions with amplitudes $<30 \mathrm{~mm} \mathrm{Hg}$, (3) failed peristalsis in which the peristaltic wave does not traverse the entire length of the distal esophagus, or (4) absent peristalsis ${ }^{(18)}$. The number of ineffective contractions (peristaltic failure and/or the number of low amplitude waves in the distal esophagus) observed were used to quantify the alterations that constitute IEM. IEM was rated as mild to moderate when $30 \%-80 \%$ of contractions were ineffective and severe when this change was present in more than $80 \%$ of wet swallows ${ }^{(17)}$.

\section{Esophageal 24h pH monitoring}

Intraesophageal $\mathrm{pH}$ monitoring was performed using a portable digital system (Synectics Medical, MK III, Stockholm, Sweden or Alacer Corp, SP, Brazil or Sigma, MG, Brazil) coupled to an antimony catheter positioned 5 $\mathrm{cm}$ above the upper limit of the LES previously defined by manometry and connected to an external reference electrode. Proton pump inhibitors (PPIs) were discontinued for 10 days, H2-receptor antagonists for 72 hours and prokynetics for 24 hours before the test. Patients were instructed to carry out their usual daily activities, on a liberal diet and avoiding only carbonated drinks and citrus fruits. A diary was kept of food and fluid intake, symptoms, and time spent in the supine and upright positions. A reflux episode was defined when esophageal $\mathrm{pH}$ dropped below 4 for at least 15 seconds. Patients with $\mathrm{pH}$ less than 4 for more than $4.5 \%$ of the total time recorded, $7 \%$ of the time in upright position and $2.5 \%$ of the time in supine position were considered as having increased esophageal acid exposure ${ }^{(12)}$.

\section{Statistical analysis}

The duration of symptoms, prevalence of hiatal hernia and manometric and $\mathrm{pH}$ monitoring data (total, upright and supine) for the SSBE and LSBE groups were compared. Statistical tests included Student's $t$ - and $\chi^{2}$ and the significance level was $P<0.05$.

\section{RESULTS}

Seventy-four patients met the inclusion criteria for the study, with 46 placed in the SSBE group (24 males, 62.2\%) and 28 in the LSBE group (18 males, 64.6\%) $P=0.308$. Ages ranged from 26 to 79 years, mean $55.22 \pm 13.56$ years (median 54 years) in the SSBE group and 30 to 86 years, mean $51.75 \pm 12.56$ years (median 50.5 years) in the LSBE group $(P=0.218)$.

The duration of symptoms (obtained for $31 / 46$ patients in the SSBE group and for $18 / 28$ in the LSBE group) was 
5-30 years (mean, $9.88 \pm 8.76$ years, median 6 years) and $1-40$ years (mean $12.94 \pm 11.66$, median 10 years), respectively, $(P$ $=0.484)$. The prevalence of hiatal hernia was high in both groups (Table 1) and there was no statistically significant difference between them $(P=0.224)$. Table 2 shows esophageal manometry LES data for the two groups.

Esophageal body manometry data is shown in Table 3. Aperistalsis and IEM were found in patients of both groups. Nutcracker esophagus (two patients) and segmental nutcracker esophagus (one patient) were found only in SSBE group. These esophageal body abnormalities were found in 28/46 $(60.87 \%)$ of the SSBE group and in $16 / 28(57.14 \%)$ of the LSBE group, none of them were statistically different between the groups.

Esophageal $\mathrm{pH}$ was monitored in 29 of the 46 SSBE patients and in 15 of the LSBE 28 patients for $24 \mathrm{~h}$. The results of the three variables, $\%$ total time $\mathrm{pH}<4, \%$ time $\mathrm{pH}<4$ upright and $\%$ time $\mathrm{pH}<4$ supine, can be seen in Table 4 .

TABLE 1. Hiatal hernia prevalence

\begin{tabular}{cccc}
\hline & SSBE $+\mathbf{n}=46$ & LSBE $\$ \mathbf{n}=28$ & $P$-value \\
\hline Hiatal hernia & $32 / 38(84.2 \%)$ & $26 / 27(96.3 \%)$ & $P=0.224$ \\
\hline
\end{tabular}

$\dagger=$ Short segment Barrett esophagus

$\ddagger=$ Long segment Barrett esophagus

TABLE 2. LES manometric data $(\mathrm{n}=73)$

\begin{tabular}{lccc}
\hline & SSBE $\dagger \mathrm{n}=46$ & LSBE $\$ \mathrm{n}=27$ & $P$-value \\
\hline Mean LE SP $\$$ & $9.15 \mathrm{~mm} \mathrm{Hg} \pm 7.06$ & $6.99 \mathrm{~mm} \mathrm{Hg} \pm 8.28$ & $P=0.066$ \\
LES $\$$ & $29 / 44(65.9 \%)$ & $23 / 28(82.1 \%)$ & $P=0.180$ \\
hypotension & & & \\
\hline$\dagger=$ short segment Barrett esophagus & \\
$\dagger=$ long segment Barrett esophagus \\
$\S=$ lower esophageal sphincter
\end{tabular}

TABLE 3. Esophageal body manometry data

\begin{tabular}{lccc}
\hline & SSBE $\uparrow \mathrm{n}=46$ & LSBE $\$ \mathrm{n}=28$ & $P$-value \\
\hline Aperistalsis & $3(6.5 \%)$ & $1(3.6 \%)$ & $P=1.00$ \\
Mild/moderate & $16(34.8 \%)$ & $13(46.4 \%)$ & $P=0.338$ \\
IEM $\S$ & $5(10.9 \%)$ & $2(7.1 \%)$ & $P=0.703$ \\
Severe IEM $\S$ & $4(8.6 \%)$ & $0(0 \%)$ & $P=0.291$ \\
NE/Seg NE q & $18(39.1 \%)$ & $12(42.9 \%)$ & $P=0.810$ \\
Normal body & &
\end{tabular}

$\dagger=$ short segment Barrett esophagus

$\pm=$ long segment Barrett esophagus

$\S=$ ineffective esophageal motility

I = nutcracker esophagus/segmental nutcracker esophagus

TABLE 4. pH monitoring data

\begin{tabular}{lccc}
\hline & SSBE $\mathrm{n}=29$ & LSBE $\mathrm{n}=15$ & $P$-value \\
\hline$\%$ total time $\mathrm{pH}<4$ & $9.12 \pm 9.61$ & $17.27 \pm 18.84$ & $P<0.000^{*}$ \\
$\%$ time $\mathrm{pH}<4$ upright & $11.91 \pm 17.28$ & $24.29 \pm 16.85$ & $P=0.003^{*}$ \\
$\%$ time $\mathrm{pH}<4$ supine & $10.86 \pm 18.77$ & $33.26 \pm 24.58$ & $P=0.000^{*}$ \\
\hline
\end{tabular}

$*$ = statistically significant difference between the two groups

\section{DISCUSSION}

The exact pathophysiology that leads to the development of Barrett's epithelium remains to be fully elucidated ${ }^{(5)}$. Possible explanations for intestinal metaplasia include the duration of reflux disease, the composition of the refluxate, and/or underlining genetic traits ${ }^{(11)}$. The most accepted theory is that this process takes place within a short period of time during which Barrett's epithelium reaches its maximum length, with little progression or regression happening thereafter ${ }^{(2,21)}$. The other theory is based on progressive stepwise growth, starting with intestinal metaplasia at the esophagogastric junction. With the weakening of the LES and continuous acid exposure, this would progress to the distal esophagus and in time would lead to a complete loss of LES function and consequently to the progression of metaplasia to more proximal esophageal segments. The development of Barrett's epithelium would therefore be a dynamic phenomenon, with its extent determined by the severity of functional abnormalities ${ }^{(4,12)}$.

Among BE risk factors, the male gender is a constant in both groups. The average age is in the fifties, with no statistical difference between groups. Several other studies confirm these findings ${ }^{(1,4,5,10,11,12)}$ and present a profile of patients who are Caucasian men mainly, over 50 with longstanding heartburn ${ }^{(20)}$.

The mean age similarity between the two groups is one of the arguments against the possibility of progression in the length of Barrett's mucosa. If there were such a progression, the SSBE group would be younger than the LSBE group, thus, there must be other mechanisms at work in the development of Barrett's metaplasia ${ }^{(10)}$.

As this was a retrospective study, information about symptom onset time, which would characterize the duration of the disease, could not be obtained for all patients, but there was no statistical difference between groups. Other authors, however, have indicated a longer duration of symptoms in $\operatorname{LSBE}^{(12)}$.

The presence of hiatal hernia is a frequent feature of patients with GERD especially in a complicated form like Barrett esophagus. In this sample, hiatal hernia was observed in $84.2 \%$ of patients with SSBE and in $96.3 \%$ of those with LSBE. The literature shows a $30 \%$ to $75 \%$ prevalence of hiatal hernia for the SSBE group with $72 \%$ to $100 \%$ for the LSBE group ${ }^{(4,5,8)}$. One study evaluated the size of hiatal hernias and found more voluminous hernias in $\mathrm{LSBE}^{(5)}$. Nowadays, hiatal hernia is among the risk factors for Barrett's esophagus. A study ${ }^{(7)}$ found a similar prevalence of hiatal hernia among patients with BE (including SSBE and LSBE), erosive disease and non-erosive reflux disease. However, the study also showed a higher prevalence of larger hernias in BE.

In evaluating LES, it was found that the mean pressure drop was more pronounced in the LSBE group with a tendency toward a statistically significant difference. This is also mentioned by some authors ${ }^{(4,10,21)}$, but not by others $^{(11,12)}$. 
LES hypotension (LES pressure below $10 \mathrm{~mm} \mathrm{Hg}$ ) was found in $65.9 \%$ of SSBE and $82.1 \%$ of LSBE patients, with no statistically significant difference. In those series in which this aspect was different, there were values of $65.9 \%$ and $73.3 \%$ for the SSBE and values of $94.1 \%$ and $93.8 \%$ for the LSBE patients ${ }^{(11,12)}$ with statistical difference between groups.

Due to the retrospective nature of this study, wave amplitude and wave velocity were not evaluated in both groups. It is questioned whether these data may have relevance.

Ineffective esophageal motility (IEM) was defined by Leite et al. ${ }^{(8)}$, as the presence of distal low amplitude peristaltic waves or peristaltic failure in at least $30 \%$ of swallows and is the principal motor disorder found in GERD ${ }^{(21)}$. In this study, IEM was categorized as mild/moderate when low amplitude or failure occurred in $80 \%$ of swallows and as severe when it occurred in more than $80 \%$ of swallows ${ }^{(17)}$. The relationship between length of Barrett's esophagus and severity of IEM could not be confirmed because there was no difference between the groups. The average amplitude of distal esophageal body waves decreased, with no difference between the SSBE and LSBE groups as many authors have already described ${ }^{(4,6,10,12)}$. However, this observation can not be made in this study.

High amplitude distal peristaltic waves, which characterize NE, may be associated with non-cardiac chest pain and dysphagia ${ }^{(15)}$. Some studies have shown that $\mathrm{NE}$ is associated with reflux in $30 \%$ to $40 \%$ of patients diagnosed by $\mathrm{pH}$ monitoring; erosive esophagitis is a rare finding ${ }^{(15,16)}$. In this study we found NE associated with $8.6 \%$ of SSBE patients and none of the LSBE patients. In a study by Csendes et al. ${ }^{(4)}$ of $80 \mathrm{NE}$ patients, $22(27.5 \%)$ had esophageal SSBE; none had LSBE.

The $\mathrm{pH}$ monitoring to quantify acid reflux in patients with a confirmed diagnosis of BE, especially LSBE, is not routine. With SSBE, the test is ordered more frequently. The reason for this is that some patients do not exhibit typical reflux symptoms and unlike what happens with LSBE, many do not show abnormal reflux. $\mathrm{pH}$ monitoring was performed on 29 of the 46 patients with SSBE and in 15 of 28 of the LSBE patients, without the use of anti-secretory drugs. Several studies show that BE patients have greater esophageal acid exposure than other GERD groups and control subjects ${ }^{(3,19)}$. More pronounced acid reflux in patients with LSBE than SSBE was also identified by several other authors ${ }^{(4,11,12,21)}$. In the present study we found that not only the percentage of total time, but also the percentages of time in upright and supine positions were also higher in the LSBE group $^{(5,8,10)}$. Thus, a direct correlation between BE length and acid exposure could be shown.

Duration of acid exposure may not be the only factor contributing to the length of Barrett's esophagus. Duodenal reflux may also be an important factor in its appearance and reaching its maximum length. Two studies that monitored the presence of bilirubin in the lower esophagus by spectrophotometry showed no difference between the SSBE and LSBE groups ${ }^{(4,11)}$.

A study using $\mathrm{pH}$-impedance in patients with mild erosive GERD, non-erosive GERD and BE, concluded that the nonerosive GERD and BE patients presented higher exposure to non-acid reflux $(\mathrm{pH}>4)$ in the supine position, in addition to increased acid exposure in both upright and supine positions. This suggests that nocturnal non-acid exposure could play a role in BE pathogenesis ${ }^{(7)}$. However, these data need to be interpreted with caution, another study using both $\mathrm{pH}$-impedance and bilimetry on patients who had typical GERD symptoms refractory to proton pump inhibitor therapy or atypical symptoms revealed that non-acid reflux and bilirubin reflux are distinct phenomena that require distinct evaluation techniques ${ }^{(13)}$. $\mathrm{pH}$-impedance cannot describe the composition of the refluxate, only its physical status and $\mathrm{pH}$. Therefore, the finding of increased non-acid reflux in BE may not correlate with the amount of bile reflux. More studies are needed to clarify this point.

In conclusion, there was no difference between the prevalence of motor disorders in patients with SSBE and LSBE. Acid reflux was more intense in BE in total time, upright and supine positions.

Helman L, Biccas BN, Lemme EMO, Novais P, Fittipaldi V. Alterações manométricas e intensidade do refluxo no esôfago de Barrett curto e longo. Arq Gastroenterol. 2012;49(1):64-8.

RESUMO - Contexto - O esôfago de Barrett (EB) se caracteriza pela presença de metaplasia intestinal no esôfago distal, quando menor que $3 \mathrm{~cm}$ é chamado Barrett curto (EBC) e com $3 \mathrm{~cm}$ ou mais Barrett longo (EBL). Sugere-se que o EBL cursa com mais alterações motoras esofagianas e com refluxo mais intenso que o EBC. Objetivo - Avaliar a prevalência de alterações manométricas e a intensidade do refluxo gastroesofágico à pHmetria em pacientes com EBC e EBL. Métodos - Estudo retrospectivo de pacientes com endoscopia digestiva alta e comprovação histopatológica de EB, divididos em dois grupos: EBC e EBL. Foram avaliados os dados demográficos, o tempo de doença, prevalência de hérnia hiatal, dados obtidos à esofagomanometria e pHmetria. Resultados - EBC 46 pacientes ( 24 masculino 52,2\% e média de idade de 55,22 anos), EBL 28 pacientes (18 masculino 64,3\% e média de idade 50,5 anos); tempo de sintomas: EBC 9,88 anos e EBL 12,94 anos; hérnia de hiato: EBC 84,2\%, EBL 96,3\%; pressão média do esfíncter inferior do esôfago: EBC 9,15 mm Hg, EBL 6,99 mm Hg; hipotensão do esfíncter inferior do esôfago: EBC 65,9\%, EBL 82,1\%; motilidade esofagiana ineficaz (MEI) leve/moderado: EBC 34,8\%, EBL 46,4\%; MEI acentuado: EBC 5 10,9\%, EBL 7,1\%; aperistalse: 6,5\%, EBL 3,6\%; esôfago em quebra-nozes: EBC 8,6\%, EBL 0\%; corpo normal: EBC 39,1\%, EBL 42,9\%, sem diferença estatística para qualquer desses valores $(P<0,05)$. Médias de pHmetria: \% de tempo total com pH <4: EBC (29/46) 9,12\% EBL (15/28) 27,27\% $P<0,000$; \% de tempo ereto com pH<4: EBC 11,91\%, EBL 24,29\% $P=0,003 ; \%$ de tempo supino com pH <4: EBC 10,86\% EBL 33,26\% $P=0,000$. Conclusões - Não houve diferença entre a prevalência das alterações motoras em pacientes com EBC e EBL. O refluxo ácido, tanto em posição ereta como em posição supina, foi mais intenso no EBL.

DESCRITORES - Esôfago de Barrett. Refluxo gastroesofágico. Manometria. Transtornos da motilidade esofágica. 


\section{REFERENCES}

1. Achem SR, Kolts BE, Burton L. Segmental versus diffuse nutcracker esophagus: an intermittent motility pattern. Am J Gastroenterol. 1993;88:847-51.

2. Cameron AJ, Lomboy CT. Barrett's esophagus: age, prevalence, and extent of columnar epithelium. Gastroenterology. 1992;103:1241-5.

3. Champion G, Richter JE, Vaezi MF, Singh S, Alexander R. Duodenogastroesophageal reflux: relationship to $\mathrm{pH}$ and importance in Barrett's esophagus. Gastroenterology. 1994,107:747-54

4. Csendes A, Smok G, Quiroz J, Burdiles P, Rojas J, Castro C, Henríquez A. Clinical, endoscopic, and functional studies in 408 patients with Barrett's esophagus, compared to 174 cases of intestinal metaplasia of the cardia. Am J Gastroenterol. 2002;97:554-60.

5. Fass R, Hell RW, Garewal HS, Martinez P, Pulliam G, Wendel C, Sampliner RE. Correlation of esophageal acid exposure with Barrett's oesophagus length. Gut. 2001;48:310-3.

6. Frazzoni M, Manno M, De Micheli E, Savarino V. Pathophysiological characteristics of the various forms of gastro-oesophageal reflux disease. Spectrum disease or distinct phenotypic presentations? Dig Liver Dis. 2006;38:643-8.

7. Gutschow CA, Bludau M, Vallböhmer D, Schröder W, Bollschweiler E, Hölscher AH NERD, GERD, and Barrett's esophagus: role of acid and non-acid reflux revisited with combined $\mathrm{pH}$-impedance monitoring. Dig Dis Sci. 2008;53:3076-81.

8. Leite LP, Johnston BT, Barrett J, Castell JA, Castell DO. Ineffective esophageal motility (IEM): the primary finding in patients with nonspecific esophageal motility disorder. Dig Dis Sci. 1997;42:1859-65.

9. Lemme EMO, Domingues GR, Silva LFD, Firman CG, Pantoja JAS. Esophageal manometry: preliminary values in health adult volunteers. GED Gastroenterol Endosc Dig. 2001;20:29-35.

10. Loughney T, Maydonovitch CL, Wong RK. Esophageal manometry and ambulatory 24-hour $\mathrm{pH}$ monitoring in patients with short and long segment Barrett's esophagus. Am J Gastroenterol. 1998:93:916-9.

11. Oberg S, Ritter MP, Crookes PF, Fein M, Mason RJ, Gadensytätter M, Brenner CG, Peters JH, DeMeester TR. Gastroesophageal reflux disease and mucosal injury with emphasis on short-segment Barrett's esophagus and duodenogastroesophageal reflux. J Gastrointestinal Surg. 1998;2:547-52
12. Oberg S, DeMeester TR, Peters JH, Hagen JA, Nigro JJ, DeMeester SR, Theisen J, Campos GM, Crookes PF. The extent of Barrett's esophagus depends on the status of the lower esophageal sphincter and the degree of esophageal acid exposure. J Thorac Cardiovasc Surg. 1999;117:572-80.

13. Pace F, Sangaletti O, Pallotta S, Molteni P, Porro GB. Biliary reflux and non-acid reflux are two distinct phenomena: a comparison between 24-hour multichannel intraesophageal impedance and bilirubin monitoring. Scand J Gastroenterol. 2007;42:1031-9.

14. Sharma P, Morales TG, Sampliner RE. Short segment Barrett's esophagus--the need for standardization of the definition and of endoscopic criteria. Am J Gastroenterol. 1998;93:1033-6.

15. Silva LF, Lemme EM. [Nutcracker esophagus: clinical evaluation of 97 patients]. Arq Gastroenterol. 2000;37:217-23.

16. Silva LF, de Oliveira Lemme EM. Are there any differences between nutcracker esophagus with and without reflux. Dysphagia. 2007;21:198-205.

17. Simrén M, Silny J, Holloway R, Tack J, Janssens J, Sifrim D. Relevance of ineffective oesophageal motility during oesophageal acid clearance. Gut. 2003; 52:784-90.

18. Spechler SJ, Castell DO. Classification of oesophageal motility abnormalities. Gut 2001;49:145-51.

19. Vaezi MF, Richter JE. Complicated Barrett's esophagus: role of acid and bile Am J Gastroenterol. 1994;89:1630.

20. Wang KK, Sampliner RE; Practice Parameters Committee of the American College of Gastroenterology. Updated guidelines 2008 for the diagnosis, surveillance and therapy of Barrett's esophagus. Am J Gastroenterol. 2008; 103:788-97.

21. Zentilin P, Conio M, Mele MR, Mansi C, Pandolfo N, DulbEcco P, Gambaro C, Tessieri L, Iiritano E, Bilardi C, Biagini R, Vigneri S, Savarino V. Comparison of the main oesophageal pathophysiological characteristics between shortand long-segment Barrett's oesophagus. Aliment Pharmacol Ther. 2002; 16:893-8.

Received 23/8/2011 Accepted 27/9/2011 